\title{
Consumption and Employment Effects of Income Redistribution in Pakistan
}

\author{
AFtab AHmad CheEma and MuHammad Hussain MaLiK*
}

\section{INTRODUCTION}

The argument that growth and equality are two opposite objectives and the conviction that if the former is preferred in the short run, the latter will automatically follow in the long run, though very popular in the past, have become somewhat controversial in recent years. Available evidence from the developing countries does not seem to support the 'trickle down' theory. It is being increasingly felt that the solution to the problem of poverty does not lie in mere maximization of the GNP. Economists have now started stressing the need for 'direct attack on poverty' [6, pp. 42-44] and for specific policies with growth implications for different groups in the Society [2, p. xiii] . Redistribution of income among different groups is therefore emerging as an important policy objective in many developing countries, including Pakistan.

The objective of this study is to find effects of the different income policies that increase the relative income share of the poor on the composition and level of consumption demand and the level of employment in Pakistan.

The traditional economic theory assumes that savings and investment are made primarily by the rich, and if income is transferred.from the rich to the poor, the latter would consume most of it because of their higher marginal propensity to consume and this would adversely affect the future growth of the economy. But this is only one side of the picture-the negative side. Income redistribution has another important effect - the demand effect. It is argued that a redistribution of income in favour of the poor may increase the growth potential of the economy by stimulating the demand for domestically produced and often relatively labour-intensive goods. The final and the net effect of a redistribution policy will, of course, depend on the relative strengths of the saving effect and the demand effect.

*Research Economists, Pakistan Institute of Development Economics, Islamabad 
There have been a number of studies including those by Cline [3], Lopes [9], FAO [4], Soligo [12], and Cheema [1], in which the authors have examined the demand and employment effects of income redistribution. The studies by Soligo and Cheema, based respectively on the data pertaining to 1963-64 and 1971-72, were for Pakistan. The present study is an attempt to analyse this problem in the light of the latest available data, which relate to 1979.

\section{METHODOLOGY AND DATA}

The model used in this analysis is based on the following four assumptions: (i) consumption expenditure on any good is primarily determined by the level of a family's disposable income; (ii) relative prices of different commodities do not change significantly, and for the purpose of this analysis we treat them as fixed; (iii) people do not reduce their work efforts as a result of income transfers; and (iv) there exists enough under-utilized capital stock, and there are no supply constraints.

In order to see the consumption effects of inter-group income transfers, we divided total consumption expenditure into seven groups, viz. food and drinks, clothing and footwear, personal effects, house rent and housing, furniture and fixtures, fuel and lighting, and miscellaneous commodities. The expenditure on food and drinks was divided into twelve sub-groups. The following two consumption functions, one linear and the other log-linear, were specified for each category.

$$
\begin{aligned}
& X_{i j}=a_{i}+b_{i} Y_{j}+u_{i j} \quad \ldots \quad \ldots \quad \ldots \quad \ldots \\
& \ln X_{i j}=\alpha_{i}+\beta_{i} \ln Y_{j}+e_{i j} \quad \ldots \quad \ldots \quad \ldots
\end{aligned}
$$

where

$X_{i j}=$ Average expenditure on commodity $i$ by the households in the $j$ th income group;

$Y_{j}=$ Average income of the households in the $j$ th income group;

$u_{i j}=$ Random disturbance term for linear consumption function; and

$e_{i j}=$ Random disturbance term for log-linear consumption function.

Since actual data were in terms of group averages and the numbers of households in different income groups were not the same, estimation of the consumption functions with the ordinary least-squares (OLS) method was not expected to yield efficient estimates of the coefficients because of the problem of heteroscedasticity.
We, therefore, used the GLS method to estimate the above functions ${ }^{1}$. The following other relationships were used to compute the consumption effects. For illustrative purposes we give here the log-linear version only.

$$
\begin{array}{llll}
\sum_{j} N_{j} X_{i j}=\sum_{j} N_{j} \exp .\left(\alpha_{i}+\beta_{i} \ln Y_{j}\right) & \cdots & \cdots \\
\sum_{i} N_{j} X_{i j}=\sum_{i} N_{j} \exp .\left(\alpha_{i}+\beta_{i} \ln Y_{j}\right) & \ldots & \ldots \\
\sum_{i} \sum_{j} N_{j} X_{i j}=\sum_{i} \sum_{j} N_{j} \exp . \quad\left(\alpha_{i}+\beta_{i} \ln Y_{j}\right) & \ldots & \ldots
\end{array}
$$

Equation (3) expresses aggregate expenditure on commodity $i$ by all groups, equation (4) denotes aggregate expenditure on all goods by the $j$ th group, and equation (5) presents total expenditure on all commodities by all groups.

To compute consumption expenditures corresponding to a new income distribution we changed the income $Y_{j}$ to $Y_{j}^{*}$. The latter denoting the new income level. They $Y^{*}$ s were calculated corresponding to the following policy alternatives:

1. Transfer of income from the richest 10 percent to the poorest 10 percent households.

2. Transfer of income from the richest 20 percent to the poorest 20 percent households.

3. Transfer of income from the richest 20 percent to the poorest 30 percent households.

4. Transfer of income from the richest 30 percent to the poorest 20 percent households.

The rates of income transfers for all these policy alternatives were simulated between 1 percent and 5 percent. There are different ways by which the income distribution can be changed. We do not want to go into the discussion of the actual transfer mechanism, as it is a separate issue by itself. Once we estimated the consumption functions, we computed the values for equations (3), (4), and (5) by using the estimated values of the parameters and the known values of $Y_{j}^{*}$ s. Changes in consumption expenditures were then determined on the basis of the differences between the expenditure levels corresponding to the initial and the new income levels.

Changes in the composition of consumption demand also have implications for labour utilization. If the demand increases for commodities which are produced with relatively labour intensive technology, then it is expected that some of the unemployed labour force will be absorbed in the relevant sector. Using the average

${ }^{1}$ See Rao and Miller [11, pp. 118-121], Pashardes [6, p. 231], and Koutsoyiannis [8, pp. $285-290]$. 
labour-output ratios for different commodity groups, we found the number of persons required for output corresponding to the new level of consumption demand.

The data used in this study were taken from the Household Income and Expenditure Survey, 1979 [13]. The basic sampling unit in the Survey was a "household" which was defined as "a single person living alone or a group of persons who normally live and eat together". The concept of income used in this study is that of "disposable income", i.e. the income left after the payment of all personal taxes. The proportions of sample households in the Survey for urban and rural areas did not correspond to the actual proportions. The distributions of households, incomes, and expenditures for the entire country as given in the Survey are not correct as they have been computed without assigning appropriate weights to the urban and rural values. We recalculated these distributions using weighted averages of the urban and rural values of the relevant variables, the weights being the proportions of households in the two areas.

As mentioned earlier, the data given in the Survey were for twelve income groups, and these groups were not of equal sizes. Another adjustment that we made in the data was to change the initial classification into deciles which made it easier to analyse the effects of income transfers from the richest $x$ percent households to the poorest $y$ percent households. The first and the tenth deciles were subdivided into two parts to find the average incomes and average expenditures of the poorest 5 percent and the richest 5 percent households. The transformations were done with linear interpolation.

\section{CONSUMPTION EFFECTS OF INCOME REDISTRIBUTION}

A redistribution of income from the rich to the poor can affect both the level and the composition of the aggregate demand. Whether the total demand and/or demand for certain commodities will increase, decrease, or remain constant after income redistribution depends primarily on the differences in the marginal propensities to consume (MPCs) of the rich and the poor, and the income elasticities of the demand for various commodities, which in turn depend on the shapes of the underlying consumption functions.

We estimated both linear and log-linear versions of the consumption functions as given in equations (1) and (2) for different commodities. A test based on the sum of squared residuals was applied to compare the results of linear and log-linear consumption functions. ${ }^{2}$ On the whole the results for log-linear functions were better and are reported in Table 1. For the 17 commodities included in this study,

${ }^{2}$ The test is discussed in Rao and Miller [11, pp 107-111]. The sum of squared residuals of linear and log-linear equations are not directly comparable and the residuals of linear equations are transformed to remove the problem of the measurement unit.
Table 1

Parameter Estimates of Log-Linear Consumption Functions

\begin{tabular}{|c|c|c|c|}
\hline Commodity & $\begin{array}{l}\text { Constant Term } \\
(\alpha)\end{array}$ & $\begin{array}{l}\text { Elasticity } \\
\qquad(\beta)\end{array}$ & $R^{2}$ \\
\hline Wheat and Wheat Flour & $\begin{array}{c}1.548 \\
(7.034)\end{array}$ & $\begin{array}{c}0.441 \\
(13.392)\end{array}$ & 0.999 \\
\hline Rice and Rice Flour & $\begin{array}{l}-2.446 \\
(-6.194)\end{array}$ & $\begin{array}{c}0.799 \\
(13.524)\end{array}$ & 0.998 \\
\hline Other Cereals & $\begin{array}{l}-3.467 \\
(-5.316)\end{array}$ & $\begin{array}{c}0.776 \\
(7.949)\end{array}$ & 0.988 \\
\hline Pulses & $\begin{array}{l}-0.390 \\
(-2.159)\end{array}$ & $\begin{array}{c}0.482 \\
(17.820)\end{array}$ & 0.999 \\
\hline Milk and Milk Products & $\begin{array}{l}-0.946 \\
(-2.407)\end{array}$ & $\begin{array}{c}0.829 \\
(14.079)\end{array}$ & 0.999 \\
\hline Edible Oils & $\begin{array}{l}-0.674 \\
(-4.287)\end{array}$ & $\begin{array}{c}0.617 \\
(26.202)\end{array}$ & 0.999 \\
\hline Meat, Fish, and Poultry & $\begin{array}{c}-3.943 \\
(-16.494)\end{array}$ & $\begin{array}{c}1.116 \\
(31.195)\end{array}$ & 0.999 \\
\hline Fruits and Vegetables & $\begin{array}{c}-1.569 \\
(-15.179)\end{array}$ & $\begin{array}{c}0.777 \\
(50.305)\end{array}$ & 0.999 \\
\hline $\begin{array}{l}\text { Gur, Sugar, Honey, and Sugar } \\
\text { Preparations }\end{array}$ & $\begin{array}{l}-1.231 \\
(-3.385)\end{array}$ & $\begin{array}{c}0.724 \\
(32.946)\end{array}$ & 0.999 \\
\hline Tea and Coffee & $\begin{array}{l}-2.556 \\
(-6.916)\end{array}$ & $\begin{array}{c}0.739 \\
(13.365)\end{array}$ & 0.998 \\
\hline Tobacco and Chewing Products & $\begin{array}{c}-2.726 \\
(-13.800)\end{array}$ & $\begin{array}{c}0.859 \\
(29.038)\end{array}$ & 0.999 \\
\hline Other Food and Items & $\begin{array}{c}-2.902 \\
(-11.221)\end{array}$ & $\begin{array}{c}0.931 \\
(24.039)\end{array}$ & 0.999 \\
\hline Clothing and Footwear & $\begin{array}{l}-0.736 \\
(-8.151)\end{array}$ & $\begin{array}{c}0.767 \\
(56.703)\end{array}$ & 0.999 \\
\hline Personal Effects & $\begin{array}{c}-8.018 \\
(-39.453)\end{array}$ & $\begin{array}{c}1.359 \\
(14.305)\end{array}$ & 0.988 \\
\hline House Rent and Housing & $\begin{array}{c}-2.829 \\
(-8.749)\end{array}$ & $\begin{array}{c}1.054 \\
(21.772)\end{array}$ & 0.998 \\
\hline Furniture and Fixtures & $\begin{array}{c}-5.389 \\
(-13.978)\end{array}$ & $\begin{array}{c}1.147 \\
(19.874)\end{array}$ & 0.997 \\
\hline Fuel and Lighting & $\begin{array}{c}0.190 \\
(2.325)\end{array}$ & $\begin{array}{c}0.546 \\
(44.615)\end{array}$ & 0.999 \\
\hline Miscellaneous & $\begin{array}{c}-2.678 \\
(-21.103)\end{array}$ & $\begin{array}{r}1.150 \\
(60.54)\end{array}$ & 0.999 \\
\hline
\end{tabular}

Note: Values in parentheses are $t$-ratios of the coefficients under which they appear. 
income elasticity was found to be positive, but less than one, in 13 cases. Only four commodity groups-meat, fish, and poultry; personal effects; house rent and housing; and miscellaneous goods-had elasticities greater than one.

The results of the consumption effects of income redistribution corresponding to different policies show that income transfers from the rich to the poor will change the composition as well as the level of consumption demand. The results of this analysis show that income redistribution in favour of the poor would increase the expenditures on basic consumption items like wheat, rice, other cereals, pulses, fruits and vegetables, edible oils, milk, tea and coffee, sugar, clothing and footwear, fuel and lighting, etc., while the expenditures on meat, fish and poultry, personal effects, furniture and fixtures, house rent and housing, and miscellaneous commodities would decrease. The results show that if one percent of the incomes of the richest 10 percent households is transferred to the poorest 10 percent households, the total expenditures on wheat and wheat flour, pulses, and fuel and lighting will increase by 0.19 percent, but would decrease by 0.31 percent on personal effects, by 0.08 percent on meat, fish, and poultry, and by 0.12 percent on miscellaneous commodities. If the rate of income transfer is 5 percent, then expenditure on wheat and wheat flour, and pulses will increase by 0.84 percent and 0.85 percent respectively, and would decrease by 1.5 percent on personal effects, and by 0.55 percent on miscellaneous commodities. The results of other income policies are all very similar with only a little difference in the numerical magnitudes. In all cases we see that income transfers from the rich to the poor leads to an increase in the demand for basic necessities (i.e. income-inelastic goods) and a decrease in the demand for luxuries (i.e. income-elastic goods).

Percentage changes in aggregate consumption expenditure with respect to various policies, positive in all cases, are given in Table 2 . The increase in aggregate consumption ranges from 0.046 percent for income transfer at a rate of one percent from the richest 10 percent to the poorest 10 percent households, to 0.316 percent for income transfer at a rate of 5 percent from the richest 30 percent to the poorest 20 percent households. The numerical magnitudes of the changes in consumption are small in all cases, mainly because of the following reasons. Firstly, income policies in the present context affect a maximum of only 30 percent households at either end of the income scale. Secondly, the level of total income is kept constant throughout the analysis. Increased consumption by one group is thus at the cost of consumption of the other. Thirdly, the rates of income transfer for all policies are very low. Greater percentage changes could be obtained only by substantial income transfers.

Besides looking at the overall effects of various income redistribution policies on demand composition another effect of such policies that we investigated was that of intergroup income transfers on the consumption levels of households in different income brackets. The results of this exercise corresponding to all the income policies are given in Table 3. In the first part of Table 3, we see that while a one-percent income transfer from the richest 10 percent households to the poorest 10 percent households decreases the consumption of the former by less than one percent, it increases the consumption of the poorest 5 percent households by 8.85 percent. The results are more dramatic if the rate of income transfer is taken as 5 percent. In that case, the consumption level of the poorest 5 percent households increases by as much as 42.97 percent and of the next 5 percent by 32.24 percent corresponding to a reduced consumption by the richest 10 percent households by less than 5 percent. In the next part we see that when income is transferred from the richest 20 percent to the poorest 20 percent households, the consumption level of the poorest 10 percent households increases by a percentage somewhat smaller (31.25) than that in the previous case. But here the beneficiaries also include 11-20 percent of the poor households whose consumption goes up by 19.46 percent (corresponding to a 5 percent income transfer). Similar changes in the consumption levels of households in different income groups are given for other policies when income is transferred from the richest 20 percent to the poorest 30 percent households, or from the richest 30 percent to the poorest 20 percent households. It is quite clear from Table 3 that in all cases the positive effects of income transfers for the poor are much stronger than the negative effects for the rich. If the marginal consumption of the poor is given a greater weight, income transfers become even more justified on social grounds.

Table 2

Percentage Change in Aggregate Consumption Expenditure

\begin{tabular}{llccccc}
\hline & \multicolumn{6}{c}{ Rate of Income Transfer } \\
\cline { 2 - 7 } Income Transfer & $\begin{array}{c}1.0 \\
\text { Percent }\end{array}$ & $\begin{array}{c}1.5 \\
\text { Percent }\end{array}$ & $\begin{array}{c}2.0 \\
\text { Percent }\end{array}$ & $\begin{array}{c}2.5 \\
\text { Percent }\end{array}$ & $\begin{array}{c}3.0 \\
\text { Percent }\end{array}$ & $\begin{array}{c}5.0 \\
\text { Percent }\end{array}$ \\
\hline $\begin{array}{l}\text { From the Richest 10\% to the } \\
\text { Poorest 10\% Households }\end{array}$ & 0.046 & 0.069 & 0.093 & 0.115 & 0.137 & 0.212 \\
& & & & & & \\
$\begin{array}{l}\text { From the Richest 20\% to the } \\
\text { Poorest 20\% Households }\end{array}$ & 0.060 & 0.089 & 0.116 & 0.114 & 0.170 & 0.269 \\
$\begin{array}{l}\text { From the Richest 20\% to the } \\
\text { Poorest 30\% Households }\end{array}$ & 0.056 & 0.080 & 0.106 & 0.132 & 0.158 & 0.251 \\
$\begin{array}{l}\text { From the Richest 30\% to the } \\
\text { Poorest 20\% Households }\end{array}$ & 0.077 & 0.110 & 0.142 & 0.175 & 0.205 & 0.316 \\
\hline
\end{tabular}


Table 3

Percentage Changes in Total Consumption Expenditures of Different Income Groups After Income Transfer from the Rich to the Poor

\begin{tabular}{|c|c|c|c|c|c|c|c|}
\hline \multirow{2}{*}{$\begin{array}{c}\text { Income Transfer } \\
\text { Policy }\end{array}$} & \multirow{2}{*}{$\begin{array}{l}\text { Households } \\
\text { (Quantiles) }\end{array}$} & \multicolumn{6}{|c|}{ Rate of Income Transfer } \\
\hline & & $1.0 \%$ & $1.5 \%$ & $2.0 \%$ & $2.5 \%$ & $3.0 \%$ & $5.0 \%$ \\
\hline \multirow{4}{*}{$\begin{array}{l}\text { Transfer of } \\
\text { Income from the } \\
\text { Richest } 10 \% \text { to } \\
\text { the Poorest } 10 \% \\
\text { Households }\end{array}$} & Poorest $5 \%$ & 8.83 & 13.19 & 17.52 & 21.82 & 26.11 & 42.9 \\
\hline & $610 \%$ & 6.57 & 9.84 & 13.07 & 16.30 & 19.52 & 32.24 \\
\hline & $91-95 \%$ & -0.88 & -1.33 & -1.77 & -2.21 & -2.65 & -4.43 \\
\hline & Richest $5 \%$ & -0.92 & -1.39 & -1.86 & -2.32 & -2.78 & -4.65 \\
\hline \multirow{7}{*}{$\begin{array}{l}\text { Transfer of } \\
\text { Income from the } \\
\text { Richest 20\% to } \\
\text { the Poorest 20\% } \\
\text { Households }\end{array}$} & Po & 6.3 & 6.87 & 12 & & & 31.25 \\
\hline & $6-10 \%$ & 4.7 & 7.10 & 9.46 & 11.79 & 14.13 & 23.38 \\
\hline & $11-20 \%$ & 3.93 & 5.89 & 7.84 & 9.80 & 11.74 & 19.46 \\
\hline & & & & & & & \\
\hline & & & & & & & \\
\hline & $91-$ & - & -1.33 & 7 & & & -4.43 \\
\hline & Richest 5\% & -0.92 & -1.39 & 6 & 32 & 78 & -4.65 \\
\hline \multirow{7}{*}{$\begin{array}{l}\text { Transfer of } \\
\text { Income from the } \\
\text { Richest } 20 \% \text { to } \\
\text { the Poorest } 30 \% \\
\text { Households }\end{array}$} & Poc & 4.2 & 6.38 & 8 & 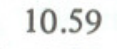 & 2.70 & 21.00 \\
\hline & $6-10 \%$ & 3.09 & 4.73 & 6.32 & 7.88 & 9.46 & 15.67 \\
\hline & $11-20 \%$ & 2.63 & 3.93 & 5.27 & 6.55 & 7.84 & 13.02 \\
\hline & $21-30 \%$ & 2.21 & 3.38 & 4.42 & 5.51 & 6.61 & 10.98 \\
\hline & $81-90 \%$ & -0.87 & -1.30 & -1.74 & -2.17 & -2.60 & -4.34 \\
\hline & $91-95 \%$ & -0.88 & -1.33 & -1.77 & -2.21 & -2.65 & -4.43 \\
\hline & Richest 5\% & -0.92 & -1.39 & -1.86 & -2.32 & -2.78 & -4.65 \\
\hline \multirow{7}{*}{$\begin{array}{l}\text { Transfer of } \\
\text { Income from the } \\
\text { Richest 30\% to } \\
\text { the Poorest } 20 \% \\
\text { Households }\end{array}$} & Poo & 8.1 & 12.13 & 16 & 20 & 01 & 39.54 \\
\hline & $6-10 \%$ & 6.04 & 9.03 & 12.01 & 14.98 & 17.93 & 29.65 \\
\hline & $11-20 \%$ & 5.01 & 7.49 & 9.98 & 12.46 & 14.91 & 24.70 \\
\hline & $71-80 \%$ & -1.86 & -1.29 & -1.72 & -2.15 & -2.58 & -4.31 \\
\hline & $81-90 \%$ & -0.87 & -1.30 & -1.74 & -2.17 & -2.60 & -4.34 \\
\hline & $91-95 \%$ & -0.88 & -1.33 & -1.77 & -2.21 & -2.65 & -4.43 \\
\hline & Richest 5\% & -0.92 & -1.39 & -1.86 & -2.32 & -2.78 & -4.65 \\
\hline
\end{tabular}

The next question that arises is how to determine whether a particular policy is better than the alternative policy or not. For example, is it better to transfer income from the richest 20 percent to the poorest 20 percent households than to transfer income from the richest 20 percent to the poorest 30 percent households? To answar this question we used the following "equal weight social utility function" suggested by Chenery [2], and computed its values for all the cases discussed above.

$$
U=\frac{1}{N}\left[N_{1} \log \left(\frac{C_{1}}{N_{1}}\right)+N_{2} \log \left(\frac{C_{2}}{N_{2}}\right)+---+N_{n} \log \left(\frac{C_{n}}{N_{n}}\right)\right]
$$

where $C_{n}, N_{n}$, and $N$ denote, respectively, total consumption expenditure of the households in the $n$th income group, the number of households in the $n$th income group, and the total number of households. The results showed that the value of this function was highest when income was transferred from the richest 30 percent to the poorest 20 percent households, in which case the function attained successively higher values as the rate of income transfer was increased from 1 percent to 5 percent.

Redistribution of income in favour of the poor can be justified not only on social but also on economic grounds. There exists ample evidence that the poor in many developing countries, including Pakistan, are under-nourished. Results in Table 3 show that consumption levels of the poorest households can be significantly increased without much adverse effects on the rich. Increased present consumption may not necessarily be at the cost of future production as assumed in many growth models, in which accumulation of physical capital occupies a pivotal position but the role of other factors, like human capital and improvements in the quality of labour, is often ignored or grossly understated. The relation between consumption and productivity is now well recognized in economic literature. It is argued that in developing countries an increase in private consumption may have positive effect on produc tivity. ". . . a rise in consumption may improve labour quality and efficiency and hence allow better use to be made of the existing labour resources. The consumption of health-improving good should improve the abilities to work and increase the intensity of work" $[10$, p. 269]. The argument has also been supported by empirica evidence. In their study about the effects of various determinants of labour quality, Galenson and Pyatt [5] have found that of all the variables included in their model, level of nutrition, as measured by the daily calories available per head, has the greatest impact on the growth of output.

As stated earlier, the net increase in the aggregate private consumption in all the cases is very small. This implies that the corresponding reduction in persona savings will also be very small. Assuming that there is no significant change in business and government savings, income transfers from the rich to the poor will lead to some reduction in the aggregate national savings, and eventually to a reduction in 
the future economic growth. There are now the following effects of income transfers from the rich to the poor - the nagative savings effect and the positive effects on demand, employment and productivity. The net result will, of course, depend on the numerical magnitudes of these effects. In the extreme case, in which the demand, employment and productivity effects are negligible, the results of this study show that the economic cost in terms of reduced saving will still be very low.

\section{EMPLOYMENT EFFECTS}

The demand for labour is primarily determined by the demand for output. Since income redistribution affects both the level and the composition of demand, and different goods are produced with different factor intensities, it also affects, though indirectly, the level of employment.

To compute employment effects of different income-transfer policies we used labour-value added ratios rather than labour-output ratios to capture, to some extent, indirect labour requirements. The labour-value added ratios are reported in Appendix Table.

The employment effects of different income-transfer policies are presented in Table 4. These effects are positive and substantial for all policies. When income is transferred from the richest 10 percent to the poorest 10 percent households at a rate of 1 percent, the jobs additionally generated number 19,313. The level of additional employment varies directly with the rate of income transfer, and at the 5 percent rate it amounts to 85,691 new jobs. Employment generation is greater in the case of income transfer from the richest 20 percent to the poorest 20 percent households than in the case of income transfer from the richest 10 percent to the poorest 10 percent households. Maximum new employment is created when income is transferred from the richest 30 percent to the poorest 20 percent households at a rate of 5 percent in which case it leads to 119,736 new jobs.

To summarise, we did not have complete information about the labour contents of different commodities. The results based on the labour-value added ratios as given in Appendix Table show only the minimum increase in the level of employment. Actual direct and indirect increases in employment are expected to be higher than are indicated by the values given in Table 4 . On the whole, the employment effect appears to be quite significant.

\section{CONCLUSION}

In this study we have analysed the effects of alternative income distributions on the consumption and employment levels in Pakistan. Starting with the initial distribution of total disposable income we have studied the implications of four different policies of income transfer from the richest $x$ percent to the poorest $y$ percent households. Our results show that any income transfers favourable to the poor will have positive effects on consumption, social welfare, and employment.
Table 4

Additional Jobs Created Under Different Income Transfer Policies

Income Transfer Rate of Income Transfer

Income Transfer

\begin{tabular}{cccccc}
\hline 1.0 & 1.5 & 2.0 & 2.5 & 3.0 & 5.0 \\
Percent & Percent & Percent & Percent & Percent & Percent \\
\hline
\end{tabular}

From the Richest $10 \%$ to the

Poorest $10 \%$ Households

$19,313 \quad 28,587 \quad 37,665 \quad 46,301 \quad 54,804 \quad 85,691$

From the Richest 20\% to the

Poorest 20\% Households

From the Richest 20\% to the

Poorest 30\% Households

20

From the Richest $30 \%$ to the

Poorest 20\% Households $\quad 27,576 \quad 40,680 \quad 52,768 \quad 65,180 \quad 76,604 \quad 119,736$

Our analysis shows that redistribution of income from the rich to the poor households will raise the consumption demand for basic necessities like, wheat, pulses, edible oils, clothing and footwear, etc. (categories which were found to be relatively income-inelastic), while the demand for personal effects; meat, fish, and poultry; furniture and fixtures; and miscellaneous commodities (categories found to be relatively income-elastic) would decrease. Increased expenditure by the poor after income redistribution would outweigh the decreased expenditure by the rich, and thus the overall effect on aggregate consumption for all income policies would be positive.

The results also show that the consumption levels of the poor households can be significantly increased with income redistribution, without much adverse effects on the rich. A policy that redistributes income from the richest 10 percent to the poorest 10 percent households at a rate of 5 percent is expected to raise the consumption level of the latter group by more than 30 percent at the cost of consumption by the former group by less than 5 percent. Income transfers of this kind, besides having welfare implications, may also be expected to have positive productivity effects.

The employment effects have also been found to be positive and quite significant for all cases. The results show that within the framework of this study the employment effects would be highest for the income policy which transfers income 
from the richest 30 percent to the poorest 20 percent households. In that case the level of employment would go up by 119,736 jobs to meet the increased demand after income redistribution at a rate of 5 percent. This is quite a high number for a developing country like Pakistan, where there exist massive unemployment and underemployment.

The results of this study, though somewhat tentative, show that income redistribution in favour of the poor may be a sound economic measure not only to raise the consumption levels of the poorest groups in the society but also to increase the level of employment and possibly the level of productivity.

\section{Appendix Table}

Labour-Value Added Ratios for Different Commodities
Commodity

Wheat and Wheat Flour

Average Daily Employment/Value Added

Rice and Rice Flour Per Year in Thousand Rupees

\section{Other Cereals}

.2075

.2075

.2075

.2075

.0681

.0119

.2075

.2075

.0209

.0360

.0083

.0176

.0663

.0751

0391

.0752

.0887

.0391

\section{REFERENCES}

1. Cheema, Aftab A. "An Analysis of Income Inequality and some Macroeconomic Implications of Income Redistribution: A Case Study of Pakistan". Unpublished Ph. D. Dissertation, University of Cincinnati, Ohio (USA) 1983.

2. Chenery, Hollis B., et al. Redistribution with Growth. London: Oxford University Press 1974.

3. Cline, William R. Potential Effects of Income Redistribution on Economic Growth - Latin American Cases. New York: Praeger Publishers. 1972.

4. Food and Agriculture Organization. "The Impact on Demand of Changes in Income Distribution: A Case Study of Eleven Latin American Countries". Monthly Bulletin of Agricultural Economics and Statistics. Vol. 21. March 1972.

5. Galenson, Walter, and Graham Pyatt. The Quality of Labour and Economic Development in Certain Countries. Geneva: ILO. 1964.

6. Haq, Mahbub ul. The Poverty Curtain. New York: Columbia University Press. 1976.

7. Kennedy, Peter. A Guide to Econometrics. Cambridge, Mass.: The MIT Press. 1979.

8. Koutsoyiannis, A. Theory of Econometrics (2nd ed.). London: McMillan. 1977.

9. Lopes, F. L. "Inequality Planning in the Developing Economy". Unpublished Ph.D. Dissertation, Harvard University, 1972.

10. Meier, Gerald M. Leading Issues in Development Economics. New York: Oxford University Press. 1964.

11. Rao, P., and R. Miller.Applied Econometrics. Belmont, California: Wadsworth. 1971.

12. Soligo, Ronald. Factor Intensity of Consumption Patterns, Income Distribution and Employment Growth in Pakistan. Houston, Texas: Rice University. 1973. (Programme of Development Studies, Paper No. 44)

13. Pakistan. Federal Bureau of Statistics. Household Income and Expenditure Survey 1979. Karachi. 1983.

14. Pakistan. Finance Division. Economic Adviser's Wing. Pakistan Economic Survey 1980-81. Islamabad. 1981.

15. Pakistan. Ministry of Planning and Development. Statistical Division. Census of Manufacturing Industries 1975-76. Karachi. n.d.

16. Pashardes, Panos. "Income Distribution, the Structure of Consumer Expenditure and Development Policy". Journal of Development Studies. Vol. 16. January 1980. pp. 224-245.

17. Paukert, F., et al. "Redistribution of Income, Patterns of Consumption and Employment-A case of Philippines". In Karen R. Polenske and Jiri V. Skolka (eds.) Advances in Input-output Analysis. Cambridge, Mass.: Ballinger Publishing Company. 1976. 


\section{Comments on}

\section{"Consumption and Employment Effects of Income Redistribution in Pakistan"}

I would first like to thank the organizers of this conference for having asked me to discuss this most interesting paper.

I had a feeling on reading the introduction that it could have been somewhat more helpful, at least to me, if it had provided a more adequate review of the literature. It appears to me that this omission may have been avoided at no great inconvenience. I may point out that in his survey article of 1975 on income distribution, W. R. Cline had cited no less than sixteen studies on simulations of income redistribution effects. In the eight years that have elapsed since that survey was published, if I am not mistaken, the literature on the subject has grown several fold.

I would next like to raise what, I suspect, most experts would consider to be a minor issue about the rationale of the kind of redistribution exercise contemplated in the paper under discussion. This exercise proposes to examine the diverse effects of a transfer of money, i.e. generalized purchasing power, from the purses of the rich to the pockets of the poor. If one were to review the numerous instruments actually employed by governments in LDCs to redistribute income, the utility of simulation exercises like the present one may be somewhat diminished. For these instruments of redistribution consist mainly not of transfers of cash, but of the transfers of real goods and services, which may consist of roads, bridges, electricity, medicine, food, and the services of doctors, nurses, teachers, and numerous experts. It will perhaps be agreed that whenever such instruments of redistribution are employed, the task of determining their impact on consumption is rendered largely superfluous. At least this may be considered to be the case for the recipients of the transfers. Of course, this is not to deny that the validity of the present exercise stands, whenever the transfers are mediated through cash. Here I may perhaps suggest that it may not be an altogether trivial exercise to determine the proportions in which income redistribution takes the two forms in the LDCs.

My next comments risk being regarded as singularly unprofessional since they refer to some of the assumptions employed by the authors. While offering these comments, I am not unaware that it is all too easy to find fault with assumptions. 
(i) To begin with, the assumption about the constancy of the relative prices in the context of direct cash transfers is relatively harmless, especially if the transfers are not unpardonably generous. However, I may point out that such a procedure may invite embarrassment if the redistribution is effected through lowering of the prices of goods abundantly consumed by the poor. In such a case, it appears to me that the consumption function to be estimated would perhaps fare better if it incorporated some variables representing relative prices.

(ii) Continuing on the subject of assumptions, it appears to me that in terms of the simplest model of household decision-making, a direct transfer of cash will lead to a diminution of effort if, considering reasonable human beings, leisure is considered a normal good. The intuitive value of such a prediction would be manifest if we considered the cases of such consumers as a poor student who works part time, or a widow who takes on domestic work, or an indigent retiree who writes letters for a fee. An extreme example of this effect has been obvious in the oil-rich countries where income transfers have reduced the labour force. In view of the above remarks, it appears to me that the assumption of unchanged effort on the part of welfare recipients may not be so innocent as to merit being left unmolested.

(iii) Further, consider the assumption of unchanged efforts and investment with regard to the rich, who under the scheme of redistribution are likely to be forced into charity. I am told that when philanthropy is demanded of the rich in this country, they usually become more zealous in their efforts. But in most cases, the increased efforts are directed at tax evasion and capital flight. And I am again told that the rich complete both these activities without any undue harassment from either the law or their own conscience.

I now come to my last but one observation. Messrs. Cheema and Malik in examining the first-round impact of income distribution have shown that this increases demand for labour-intensive goods. This good news may, however, be followed by the bad news of a reversal of this effect if we incorporate, as Soligo (1973), did the labour requirements of the not-too-commodious shelters of the rich. Cline (1975), in his survey, has warned that this exercise commits the sin of doublecounting. I must admit that on my reading of the paper, I have missed any signs of this double-counting.

Finally, I would like to draw attention to a consequence of income redistribution which has not been mentioned in the literature, i.e. the partial literature that has come to my notice. Income redistributions, where they are substantial, are likely to raise the reservation price of labour. If such a consequence materializes, this, apart from tending to lower labour supply, may have the added effect of raising labour cost with its attendant inducements for substitution of capital for labour. The last tendency may very well be impertinent enough to undo the good work that income redistribution is often shown to achieve by increasing the demand for labour-intensive goods. However, any assessment of the relative strengths of these often opposite effects must await the completion of empirical investigations. And these, as is so often the case, are not always completed while the question is still relevant.

I am sure that in the discussion that is likely to follow, some distingushed members of this audience will make up for my lack of expertise and relevance.

Applied Economic Research Centre,

M. Shahid Alam University of Karachi,

Karachi 